\title{
Functional Genomic Analysis of Global Regulator NolR in Sinorhizobium meliloti
}

\author{
Hancai Chen, ${ }^{1}$ Ke Gao,, Eva Kondorosi, ${ }^{1}$ Adam Kondorosi, ${ }^{2}$ and Barry G. Rolfe ${ }^{1}$ \\ ${ }^{1}$ Australian Research Council Centre of Excellence for Integrative Legume Research, Genomic Interactions Group, \\ Research School of Biological Sciences, Australian National University, Canberra ACT 0200, Australia; ${ }^{2}$ Institut des \\ Sciences, Végétales, CNRS, Gif-Sur-Yvette Cedex, France
}

Submitted 28 June 2005. Accepted 19 August 2005.

NolR is a regulator of nodulation genes present in species belonging to the genera Rhizobium and Sinorhizobium. The expression of the nolR gene in Sinorhizobium meliloti AK631 was investigated in relation to stage of growth, availability of nutrients, and different environmental stimuli using the nolR::lacZ fusion report system. It has been shown that the nolR gene is regulated in a population-density-dependent fashion and influenced by a number of environmental stimuli, including nutrients, $\mathrm{pH}$, and oxygen. Exploration of the physiological functions of NolR under various laboratory conditions has shown that NolR is required for the optimal growth of the bacteria on solid media, optimal survival of the bacteria in carbon-starved minimal medium, and after heat shock challenge. NolR also is involved in recipient-induced conjugative transfer of a plasmid. Proteome analysis of strain AK631 and its Tn5-induced nolR-deficient mutant EK698 revealed that a functional NolR induced significant differences in the accumulation of 20 polypeptides in peptide mass fingerprinting early-log-phase cultures and 48 polypeptides in stationary-phase cultures. NolR acted mainly as a repressor in the early-log-phase cultures, whereas it acted as both repressor and activator in the stationaryphase cultures. The NolR protein and 59 NolR-associated proteins have been identified by peptide mass fingerprinting. The NolR protein was differentially expressed only in the $\mathrm{NolR}^{+}$wild-type strain AK631 but not in its $\mathrm{NolR}^{-}$derivative EK698, confirming that no functional NolR was produced in the mutant. The NolR-associated proteins have diverse functions in amino acid metabolism, carbohydrate metabolism, lipid metabolism, nucleotide metabolism, energy metabolism, metabolism of Co-factors, and cellular adaptation and transportation. These results further support our previous proposal that the NolR is a global regulatory protein which is required for the optimization of nodulation, bacterial growth and survival, and conjugative transfer of a plasmid.

Additional keywords: cellular functions, luteolin, protein networks, quorum sensing.

Sinorhizobium meliloti forms a nitrogen-fixing symbiosis in root nodules of a group of legumes generally referred to as "medics" which includes commercially significant species such as Medicago sativa (alfalfa or lucerne) and $M$. trunca-

Corresponding author: B. G. Rolfe; Telephone. (612)-6125-4054; Fax: (612)-6125-0754; E-mail: rolfe@ rsbs.anu.edu.au tula (Australian barrel medic). During this plant-microbe interaction, bacterial nodulation (nod) gene expression is regulated both positively and negatively (Kondorosi et al. 1989a). Positive regulation is controlled by three nodD gene products and other genes (e.g., syrM, located on the megaplasmid pSymA, in conjunction with signal molecules from the host plants) (Long 1996). The NodD protein is activated by specific plant signals and the activated NodD protein then interacts with a conserved $c i s$-regulatory element (the nod-box) to coordinately regulate the common nodulation genes (Kondorosi et al. 1989a and b).

Negative regulation is mediated by a repressor protein encoded by a chromosomal nolR gene (Cren et al. 1994; Kondorosi et al. 1991). This chromosomal gene encodes a 13$\mathrm{kDa}$ protein which binds to the overlapping nodDl and nodA promoters at the RNA polymerase binding site (Cren et al. 1995). The functional NolR protein is in the dimeric form which negatively controls not only nod gene expression but also its own gene expression (Cren et al. 1995). The functional NolR protein is required for the optimal nodulation because $n o l R^{-} S$. meliloti strains are less efficient at nodule initiation and formation compared with the wild-type strain (Kondorosi et al. 1989b). It has been reported that the expression of nod genes of $S$. meliloti involved in core Nod factor synthesis is differentially downregulated by NolR which leads to the production of a low amount of fully decorated Nod factors (Cren et al. 1995). Therefore, fine tuning of Nod factor production appears to be required for optimal nodulation. These studies illustrate the interaction between the chromosomal and plasmid replicons and the finely tuned nature of the control of synthesis of the Nod factors of Sinorhizobium spp. (Cren et al. 1995).

A database search revealed that NolR was similar in size and structure to a group of small bacterial regulatory proteins (Kiss et al. 1998). The highest similarity of NolR was to a positive activator, HlyU, although it also was similar to a group of negative regulators. The possibility of NolR being both a positive and negative regulatory protein is further supported by proteomic studies on $S$. meliloti strains, with or without a functional NolR, which revealed that production of a number of proteins were up- or downregulated in the presence of a functional NolR protein (Chen et al. 2000b). Most identified NolR-associated proteins involved in various metabolic pathways and cellular functions, including the trichloroacetic acid (TCA) cycle, stress response, cell growth and maintenance, DNA transcription, and protein synthesis. It has been suggested that NolR is a global regulatory protein which responds to environmental factors to fine tune intracellular metabolism (Chen et al. 2000b). 
The NolR function also is present in species belonging to the genera Rhizobium and Sinorhizobium (Kiss et al. 1998). Recently, it has been shown that the alteration of nolR expression in $S$. fredii can affect the production of Nod factors, signal responsive (SR) proteins, and exopolysaccharide (EPS), which are three different bacterial symbiotic signals and also change its nodulation capacity on different hosts (Vinardell et al. 2004).

In Bradyrhizobium japonicum, negative regulation of the nodulation genes is mediated by NolA and NodD2. NolA activates expression of NodD2 which, in turn, leads to the repression of nod gene expression (Garcia et al. 1996). It has been demonstrated that the expression of nolA and nodD2 is population density-dependent which is mediated by quorum sensing (Loh et al. 2001). Quorum sensing is dependent on the synthesis, exchange, and perception of small signal molecules between bacteria. The population-density-dependent expression of nolA and nodD2 in B. japonicum was mediated by a novel quorum sensing signal molecule, designated bradyoxetin (Loh et al. 2002). Bradyoxetin is different from the acyl homoserine lactones (AHLs), the most widespread form of quorum sensing signal molecules found among gram-negative bacteria (BrellesMarino and Bedmar 2001). Quorum sensing plays an important role in the symbiosis between alfalfa and its symbiont $S$. meliloti. S. meliloti has at least three quorum sensing systems, Sin, Mel, and Tra (González and Marketon 2003). The Sin quorum sensing system is responsible for the production of longchain AHLs and controls production of the symbiotically active EPS II and low molecular weight succinoglycan (Hoang et al. 2004; Marketon et al. 2002). The Mel system is responsible for the production of short-chain AHLs (Marketon et al. 2002) and appears to be involved in nitrogen fixation (Hoang et al. 2004). The Tra system, which is present in strain Rm41 but not Rm1021, also is involved in the production of short-chain AHLs (Marketon et al. 2002) and controls conjugal plasmid transfer (González and Marketon 2003).
In this study, we have investigated i) the expression of the nolR in S. meliloti AK631, an exoB derivative of Rm41, in relation to the stage of growth, availability of nutrients, and different environmental stimuli using a lacZ reporter system; ii) physiological functions of NolR under various environmental conditions; and iii) proteins regulated by NolR using peptide mass fingerprinting (PMF). It has been shown that regulation of the nolR is population density dependent and influenced by a number of environmental stimuli. It also has been discovered that NolR is required for the optimal growth or survival of the bacteria grown on the solid media or under stress conditions and conjugative transfer of plasmids. Furthermore, at least 59 NolR-associated proteins have been identified.

\section{RESULTS}

\section{Population-density-dependent regulation} of the nolR expression.

The expression of the nolR gene was investigated by measuring the $\beta$-galactosidase activity of $S$. meliloti $\mathrm{NolR}^{+}$strain AK631 carrying a translational nolR::lacZ fusion inserted into its chromosome (Cren et al. 1995). Bacterial growth measured by viable cell count was parallel with that by optical density at $600 \mathrm{~nm}\left(\mathrm{OD}_{600}\right)$. An $\mathrm{OD}_{600}$ unit corresponded to approximately $10^{9}$ cells $\mathrm{ml}^{-1}$ (data not shown). A correlation between cell density and the nolR expression was observed by measuring $\beta$ galactosidase activity over the complete growth cycle of cells of AK631 carrying the nolR::lacZ fusion growing in TA medium (yeast tryptone broth; Chen et al. 2003) (Fig. 1). The $\beta$ galactosidase activity of the nolR::lacZ fusion was reduced continuously during the first $5 \mathrm{~h}$ of incubation time. When the cells grew to the early log-phase with a cell population of approximately $4.3 \times 10^{8} \mathrm{ml}^{-1}$ after $7 \mathrm{~h}$ of incubation, the $\beta$-galactosidase activity was shown to increase steadily until the cell culture reached the stationary phase. The increase of the nolR

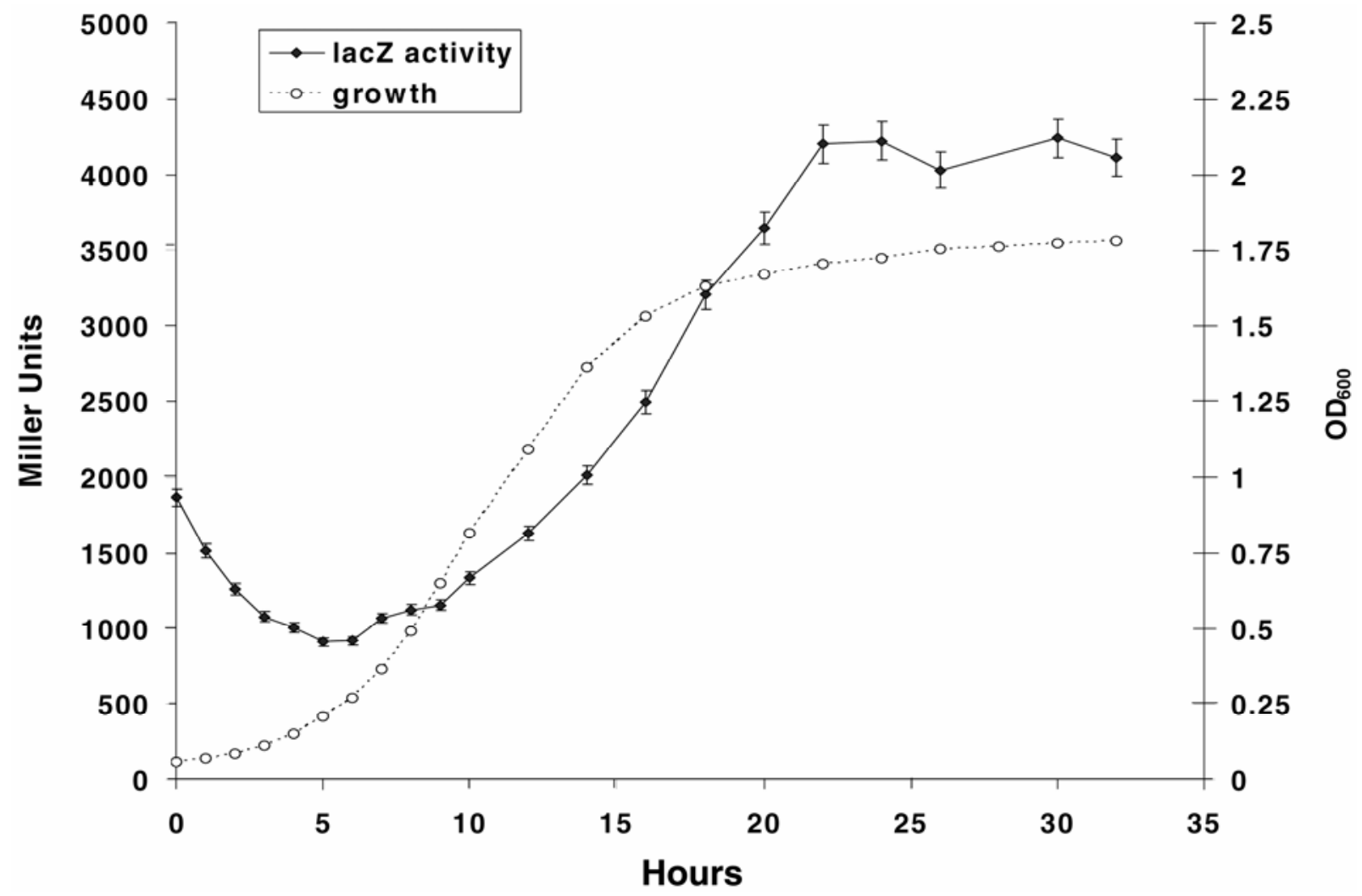

Fig. 1. Population-density-dependent expression of the nolR::lacZ fusion in Sinorhizobium meliloti AK631 grown in TA medium. 


\section{Requirement of NolR} for optimal survival under stress conditions.

Strains AK631 $\left(\mathrm{NolR}^{+}\right)$and EK698 (NolR $\left.{ }^{-}\right)$were grown in the defined BIII medium and the nutrient-limited BIII medium with much reduced carbon and nitrogen nutrients for up to 16 days. Samples of these cultures were taken out every 2 days for viable count detection. When the cells reached stationary phase after 2 days of inoculation, the viability of cells of either strain AK631or EK638 grown in the BIII medium was sustained in the prolonged stationary phase (Fig. 3 ). The cell number of both cultures grown in the nutrientlimited BIII medium reached the peak $\left(10^{9} \mathrm{CFU} \mathrm{m}{ }^{-1}\right)$ after 2 days of inoculation and then was shown to decrease steadily to a lower density $\left(10^{8} \mathrm{CFU} \mathrm{ml}^{-1}\right)$ up to 8 days of incubation, and then sustained this low density. Although there was no difference of cell viability between the $n o l R^{-}$and $n o l R^{+}$ strains during a prolonged stationary phase when cells were grown in the BIII medium, nolR ${ }^{+}$cells did survive better than the nolR $^{-}$mutant in nutrient-limited BIII medium (Fig. 3). The difference between AK631 and EK698 viability becomes apparent after 8 days. From day 8 until day 16, AK631 maintained its viability at $1 \times 10^{8} \mathrm{CFU} \mathrm{ml}^{-1}$, whereas the viability of EK698 further dropped to $4 \times 10^{7}$ from day 8 to 10 and then maintained this low viability. The half a $\log$ of difference was statistically significant. These results indicate that functional NolR is required for the optimization of stationary-phase survival of $S$. meliloti under nutrient-stressed conditions.

The physiological role of NolR also was investigated under heat-shock stress conditions. This was done by the incubation of stationary-phase cultures of strains AK631 and EK698 at 44 to $46^{\circ} \mathrm{C}$ for up to $6 \mathrm{~h}$. Viability of the heatshocked culture was detected every $2 \mathrm{~h}$ during the treatment. There was no significant difference in viability between

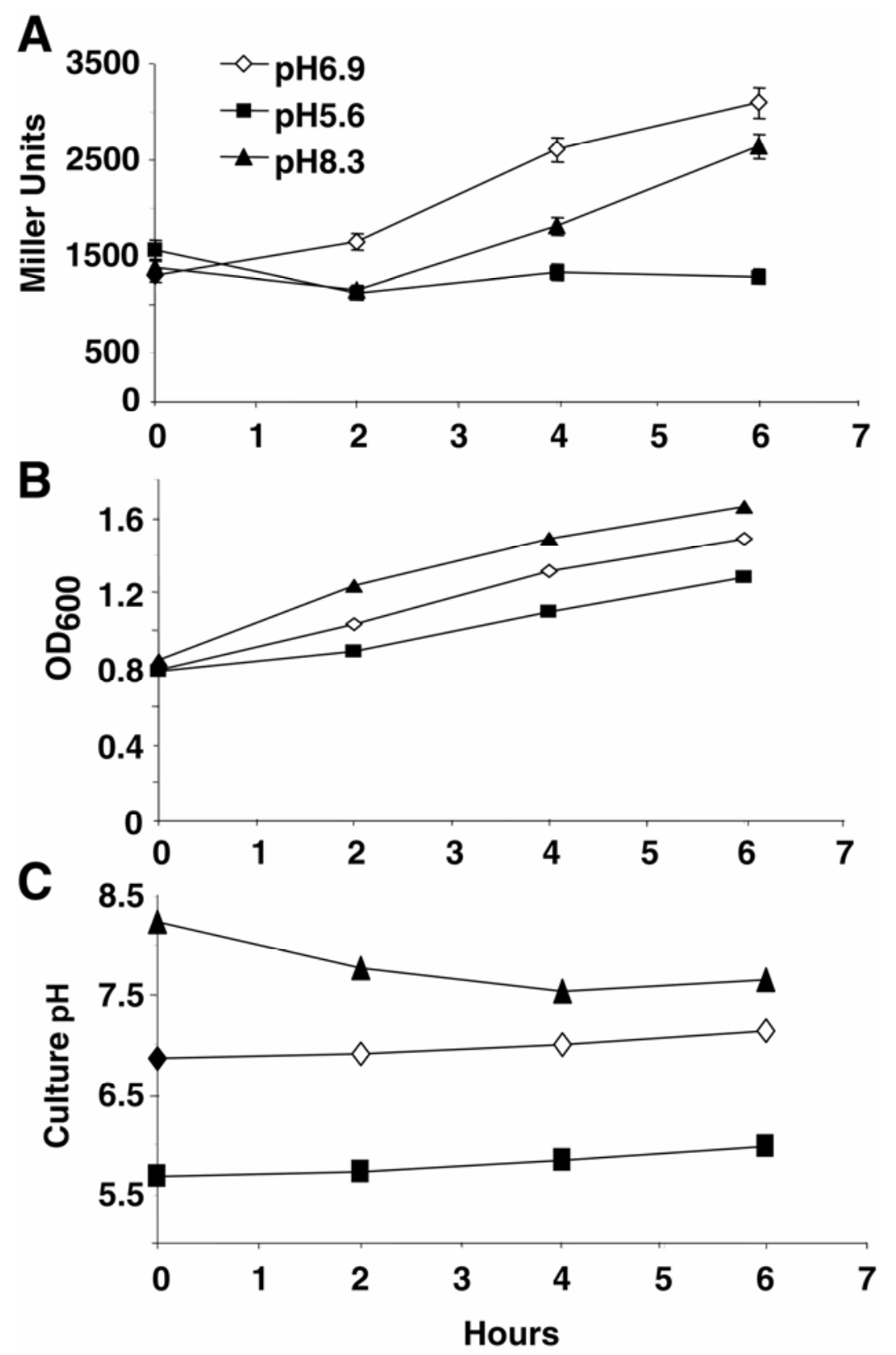

Fig. 2. Effect of $\mathrm{pH}$ shock on the nolR::lacZ expression in strain AK631. Middle-log-phase culture grown in TA medium (optical density at $600 \mathrm{~nm}\left[\mathrm{OD}_{600}\right]$ $=0.8, \mathrm{pH} 6.9$ ) was adjusted to a $\mathrm{pH} 5.6$ with $40 \mathrm{mM}$ MES and to $\mathrm{pH} 8.3$ with $1 \mathrm{M}$ Tris base. $\mathbf{A}, \beta$-Galactosidase activity, $\mathbf{B}$, cell growth, and $\mathbf{C}$, $\mathrm{pH}$ of the cultures under $\mathrm{pH}$ shock. 
AK631 and EK698 upon $45^{\circ} \mathrm{C}$ heat-shock challenge (data not shown). However, at $46^{\circ} \mathrm{C}$, a difference in viability between $\mathrm{NolR}^{+}$and NolR ${ }^{-}$cells was observed (Fig. 4). The viability of $\mathrm{NolR}^{+}$cells was statistically significant half a log higher than NolR ${ }^{-}$cells after $6 \mathrm{~h}$ of incubation at $46^{\circ} \mathrm{C}$. A closer look at the viability of $\mathrm{AK} 631$ at the $46^{\circ} \mathrm{C}$ treatment reveals a tripha- sic curve. This suggests that, between the 2-h and 6-h time course, there is a repairing system functioning within the cells of strain AK631 but not in strain EK698. Therefore, a functional NolR may play a role in the repairing mechanism to help maintain the viability of the cell under elevated temperatures.

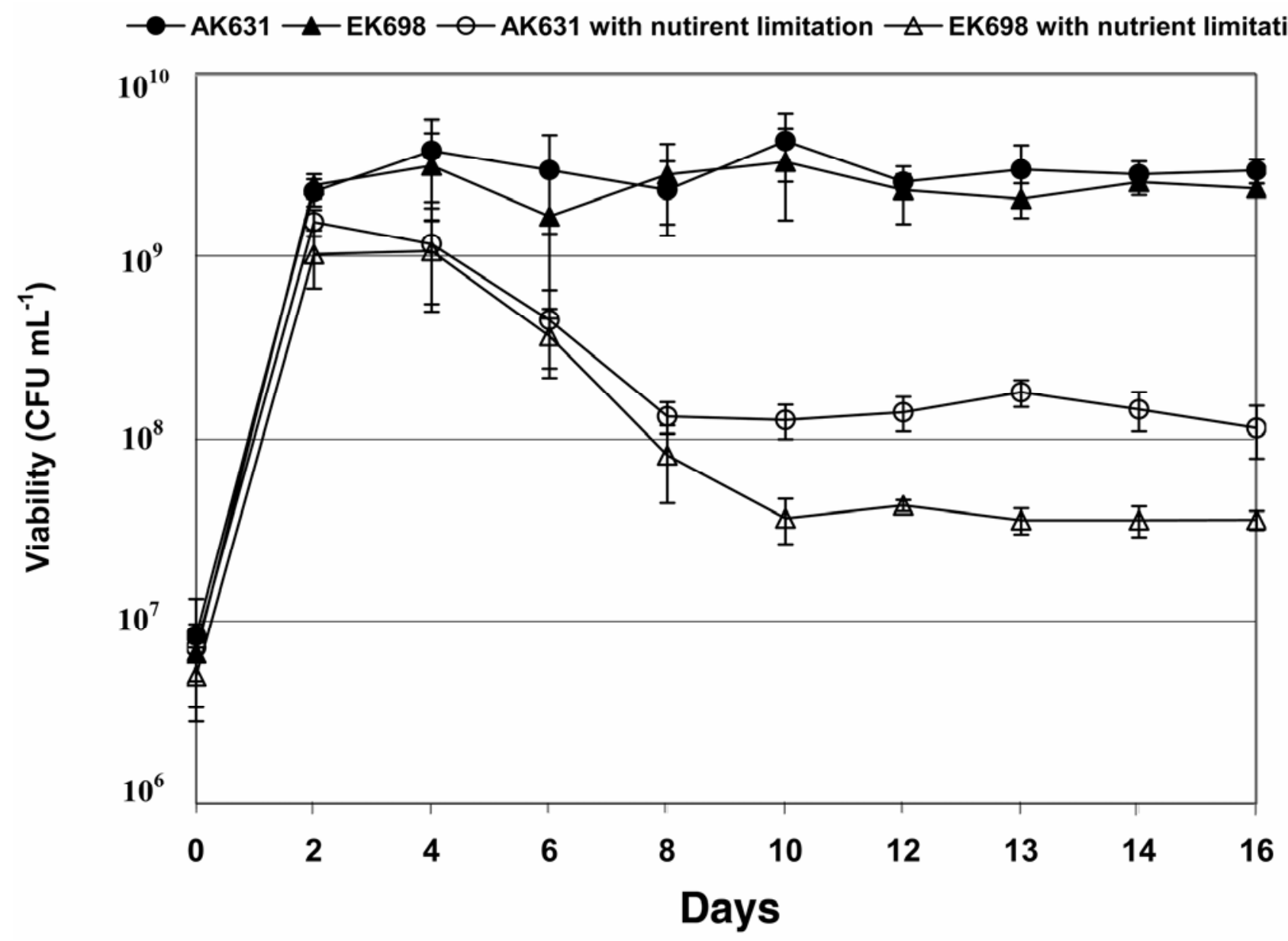

Fig. 3. Viability of strains AK631 and EK698 in BIII medium and carbon-nitrogen-limited BIII medium in prolonged stationary phase.

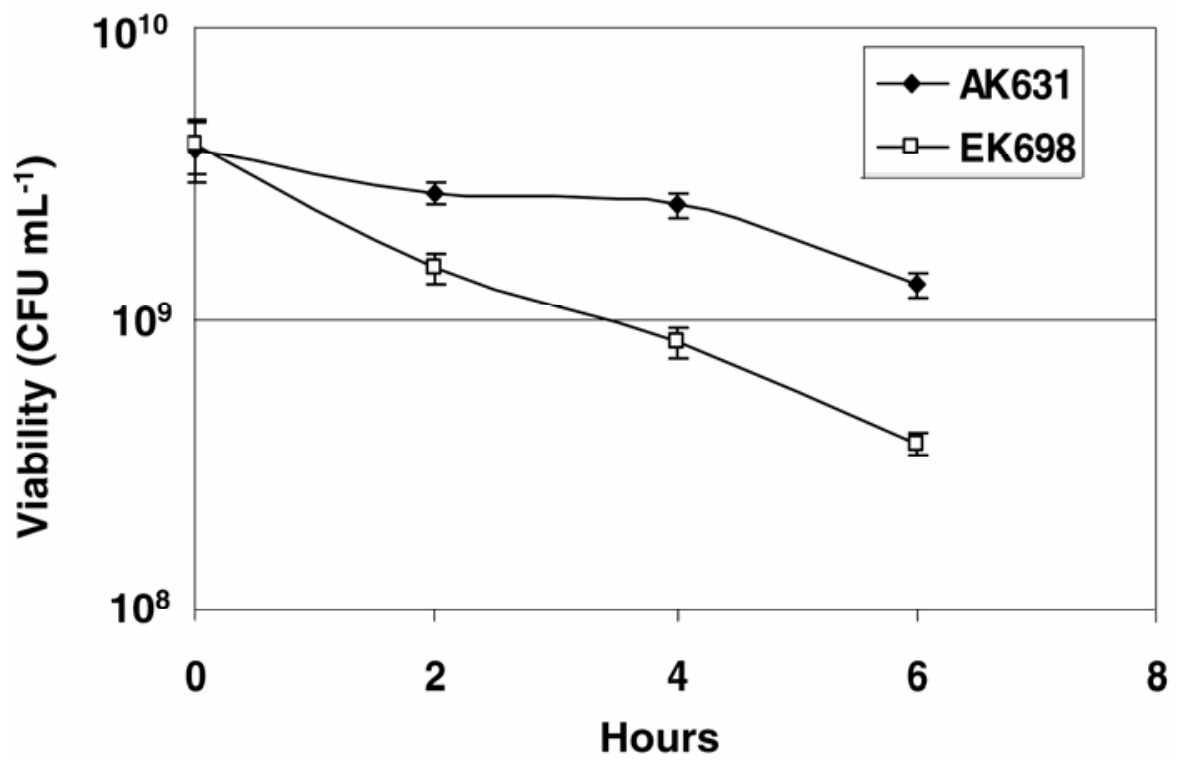

Fig. 4. Effect of $46^{\circ} \mathrm{C}$ heat shock on the viability of strains AK631 and EK698 in BIII medium. 


\section{Requirement of NolR for colony development.}

An observation on the colony size on agar plates during viable counting showed that the size of the colonies from the $n o l R^{+}$cells initially was bigger compared with that of the colonies from the nolR $R^{-}$cells. By measuring the size of colonies that appeared on the TA plates after 3 days of incubation, it was found that the average size of colonies of AK631 was $30 \%$ bigger than that of EK698. The size of colonies of AK631 was still slightly bigger $(6 \%$ bigger) than that of EK698 when the plates were incubated for 4 days. After 5 days of incubation, difference in colony size between the $n o l R^{-}$and $n o l R^{+}$cells disappeared. To see whether the smaller NolR ${ }^{-}$colonies were due to smaller cellular size or lower cell numbers in the colonies, the colonies were picked up randomly and used for viable count analysis. It was found that bigger colonies had more cells than small colonies. After 3 days of incubation on agar plates, an average AK631 colony consisted of $1.52 \times 10^{8}$ cells $\mathrm{ml}^{-1}$, whereas an average EK698 colony consisted of $7.76 \times 10^{7}$ cells $\mathrm{ml}^{-1}$. After 4 days of incubation, an average AK631 colony consisted of $5.18 \times 10^{8}$ cells $\mathrm{ml}^{-1}$, whereas an average EK698 colony consisted of $4.83 \times 10^{8}$ cells $\mathrm{ml}^{-1}$. After 5 days on agar plates, colonies of AK631 and EK698 had similar cell number (1.2 $\times 10^{9}$ cells $\mathrm{ml}^{-1}$ ). Therefore, the difference in colony size was due to different cell division rate rather than different cell expansion rate on solid medium. These results indicate that functional NolR is required for the optimization of $S$. meliloti to grow on solid media.

\section{NolR regulates Rhizobium leguminosarum bv. trifolii nodA and affects conjugal plasmid transfer.}

Kiss and associates (Kiss et al. 1998) indicated the conservation of the nolR in the genera Sinorhizobium and Rhizobium of the Rhizobiaceae family, including Rhizobium leguminosarum bv. trifolii. To detect the function of NolR of S. melilotii on regulation of nod genes of different Rhizobium spp., plasmid pRT311 (containing a transcriptional fusion between the $R$. leguminosarum bv. trifolii nodA promoter and the lacZ gene) was conjugally transferred into strains AK631 and EK698. It was found that there was a big difference in plasmid transfer frequency of pRT311 to the NolR ${ }^{+}$strain AK631 compared with the NolR ${ }^{-}$strain EK698. The transfer frequency of pRT311 to AK631 and EK698 was $1.2 \times 10^{-2}$ and $2.3 \times 10^{-4}$, respectively. The plasmid transfer frequency in AK631 was 50 times higher than that in EK698, indicating that NolR plays a role in conjugal plasmid transfer. In the presence of luteolin, the $\beta$-galactosidase activity of $\mathrm{NolR}^{+} \mathrm{AK} 631$ carrying plasmid
pRT311 was $60 \%$ of that shown by its NolR $^{-}$derivative EK698 carrying plasmid pRT311, indicating that NolR of S. melilotii is also functional on the expression of $R$. leguminosarum bv. Trifolii nodA.

\section{Effects of NolR on protein accumulation in wild-type $S$. meliloti AK631.}

When two-dimensional (2D) maps of $\mathrm{NolR}^{+} \mathrm{AK} 631$ and NolR $^{-}$EK698 were compared, one protein (spot 93) was found to exist only in AK631 but not in EK698 (Fig. 5; Table $3)$. The molecular weight (MW) and isoelectric point $(\mathrm{p} I)$ of spot 93 on the gel were $13.2 \mathrm{kDa}$ and 6.4 , respectively, which were close to the theoretical MW (13.3 kDa) and $\mathrm{p} I(6.1)$ of AK631 NolR. PMF analysis showed that this protein is highly homologues to $S$. meliloti NolR in the SwissProt database (Table 3). PMF of spot 93 also was matched to NolR in the $S$. meliloti 1021 genome database, although the confidence of the match is low (data not shown). This is due to a single insertional mutation in the C-terminal coding sequence of the nolR gene of 1021 which caused the open reading frame to be elongated by 50 amino acids, resulting in a 172-amino-acid-long, 18.8-kDa protein (Cren et al. 1995). No equivalent protein spot of NolR was found on the $2 \mathrm{D}$ gels used to analyze the NolR ${ }^{-}$EK698, which demonstrates that no functional NolR has been produced in strain EK698. The NolR spots of the early exponential phase and stationary phase of strain AK631 were quantified and compared. It was found that the accumulation of NolR in stationary phase was $175 \%$ of that of in the early log phase (Table 3 ). The higher accumulation of NolR in the stationary phase corresponds to the higher expression of the nolR in the stationary phase (Fig. 1).

The accumulation of 59 protein spots was affected reproducibly and significantly by a functional NolR when the protein profiles of strains AK631 and EK698 grown in the TA medium at the stages of early log phase $\left(\mathrm{OD}_{600}=0.2\right)$ and stationary phase $\left(\mathrm{OD}_{600}=1.8\right)$ were compared on the $2 \mathrm{D}$ gels. The difference in the accumulation of the 59 protein spots in the NolR EK698 background is shown in Table 3. In early-log-phase cultures, 20 protein spots showed changes of at least 1.5- to 8fold in accumulation. Among the 20 spots, 17 were increased and 3 were decreased in protein accumulation level. In stationary-phase cultures, however, 48 protein spots were altered in accumulation level at least 1.5- to 4-fold. Of the 48 spots, 25 were increased and 23 were decreased in protein accumulation level. Nine protein spots were altered in protein accumulation level in both early-log-phase and stationary-phase cultures,
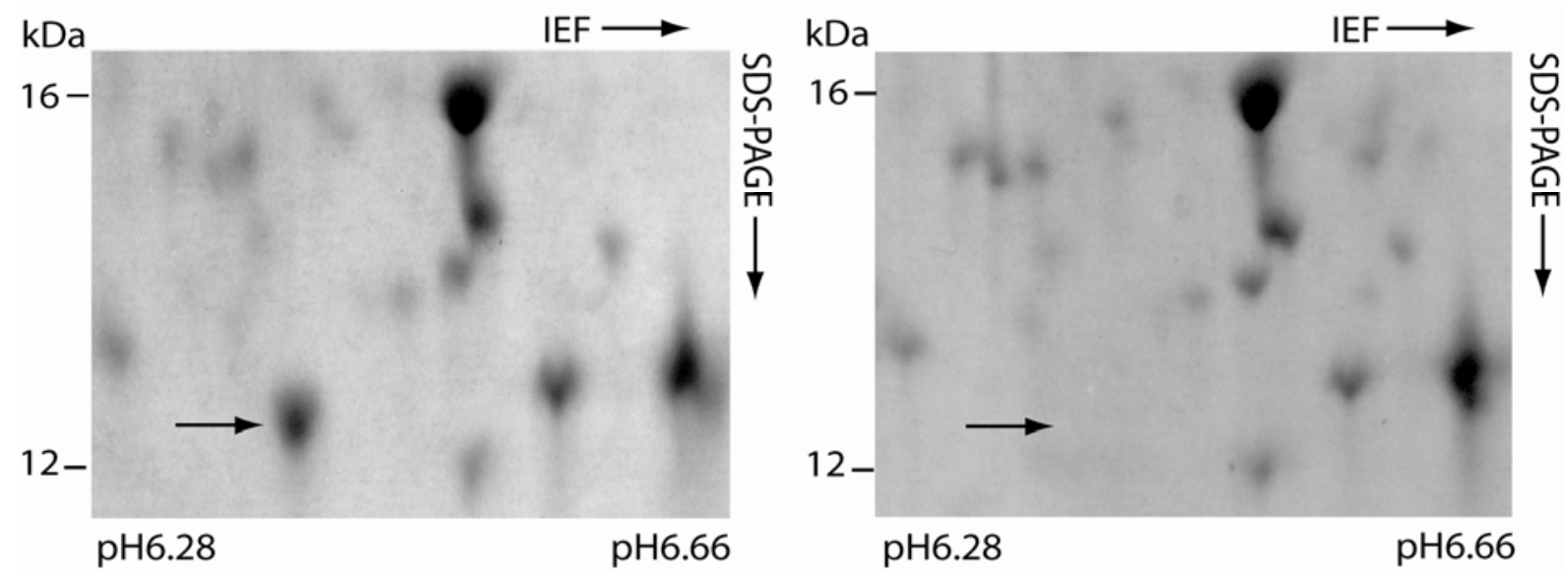

Fig. 5. Enlarged views of the region containing NolR protein of Sinorhizobium meliloti (arrows show the position of the NolR spot). Left, AK631 with a functional NolR; right, EK698 without a functional NolR. SDS-PAGE = sodium dodecyl sulfate polyacrylamide gel electrophoresis. 
with six of the nine spots having increased or decreased protein levels in the both growth phase cultures and three having increased protein levels in the early-log-phase cultures but decreased protein levels in the stationary-phase cultures. The 59 NolR-associated polypeptides were identified by PMF and correspond to 54 proteins in the $S$. meliloti 1021 protein database (Table 3). These include 3 pSymA, 9 pSymB, and 47 chromosomal gene products.

\section{Proteins associated with NolR, AHLs, and bacteroids.}

Natera and associates reported that over 600 proteins of $S$. meliloti 1021 were up- or downregulated in the bacteroid form of the rhizobia compared with cultured cells (Natera et al. 2000). Also, proteomic studies of strain 1021 responding to the addition of AHL quorum sensing signals have identified a number of AHL-associated proteins (Chen et al. 2003, Teplitski et al. 2004). A possible overlap of protein networks regulated by NolR, AHLs, and in the bacteroid is shown in Table 4 . In all, 12 NolR-associated proteins were found to be affected by
AHLs or in the bacteroid, and 4 of the 12 NolR-associated proteins also were expressed differentially by the addition of AHLs and in the bacteroid.

\section{DISCUSSION}

NolR expression during the growth cycle.

By examining the patterns of nolR expression throughout the complete growth cycle of $S$. meliloti carrying a nolR-lacZ fusion, evidence supporting a population-density-dependent regulation of nolR expression has been demonstrated. Once cell growth of strain AK631 carrying a nolR::lacZ fusion was stopped by the exposure of the bacterial culture to conditions which affect its cellular growth, such as in an anaerobic environment or when deprived of nutrients, the level of nolR expression remained unchanged unless oxygen or nutrients were provided. These findings indicate that the elevation of nolR activity only occurred in a growing cell. Because the growing cells change culture population density, the correlation be-

Table 3. Proteins differentially accumulated in early log phase and stationary phase cultures of NolR ${ }^{-}$Sinorhizobium meliloti EK698

\begin{tabular}{|c|c|c|c|c|c|c|c|c|c|c|}
\hline \multirow[b]{2}{*}{ Spot no. } & \multirow[b]{2}{*}{ Accession $^{d}$} & \multirow[b]{2}{*}{ Protein description } & \multicolumn{3}{|c|}{$\begin{array}{l}\text { Protein accumulation } \\
\text { response }(\%)^{\mathrm{a}}\end{array}$} & \multicolumn{3}{|c|}{ Mascort search results ${ }^{b}$} & \multicolumn{2}{|c|}{$\mathrm{MW} / \mathrm{p} I^{\mathrm{c}}$} \\
\hline & & & Early & Stationary & Rating ${ }^{\mathbf{e}}$ & Score & Peak & Seq. $(\%)$ & Exp. & Theor. \\
\hline 30 & SMa1200 & Hypothetical protein & 65 & & 3 & 55 & 5 & 37 & $17,754 / 5.08$ & $17,202 / 4.84$ \\
\hline 43 & SMa1227 & fixJ, FixJ transcriptional activator & $\ldots$ & 269 & 3 & 104 & 9 & 56 & $23,954 / 5.46$ & $22,204 / 5.12$ \\
\hline 19 & SMa1313 & virB5, VirB5 type IV secretion protein & & 32 & 3 & 104 & 7 & 58 & $24,527 / 4.66$ & $22,616 / 4.72$ \\
\hline 92 & SMb20021 & Transcriptional regulator & 836 & $\ldots$ & 1 & 34 & 3 & 42 & $14,584 / 6.58$ & $17,309 / 5.32$ \\
\hline 20 & SMb20127 & Hypothetical protein & $\ldots$ & 56 & 3 & 99 & 7 & 35 & $33,080 / 4.67$ & $34,545 / 4.88$ \\
\hline 22 & SMb20127 & Hypothetical protein & $\ldots$ & 16 & 3 & 99 & 7 & 35 & $33,311 / 4.84$ & $34,545 / 4.88$ \\
\hline 32 & SMb20343 & Aldehyde dehydrogenase subunit & $\ldots$ & 70 & 1 & 38 & 3 & 36 & $16,542 / 5.11$ & $16,109 / 4.96$ \\
\hline 73 & SMb20703 & Conserved hypothetical protein & $\ldots$ & 65 & 3 & 51 & 3 & 40 & $31,954 / 6.50$ & $18,698 / 6.19$ \\
\hline \multirow[t]{2}{*}{72} & SMb20751 & (1.1.1.31) Putative 3-hydroxyisobutyrate & & & & & & & & \\
\hline & & dehydrogenase & 358 & & 3 & 79 & 6 & 45 & $29,841 / 6.41$ & $30,268 / 5.89$ \\
\hline 14 & SMb20895 & chvE, Proline iminopeptidase & $\ldots$ & 55 & 3 & 85 & 7 & 31 & $34,725 / 4.41$ & $37,845 / 4.48$ \\
\hline \multirow[t]{2}{*}{8} & SMb21037 & Putative oligopeptide/murein peptide & & & & & & & & \\
\hline & SMb21566 & $\begin{array}{l}\text { ABC transporter periplasmic } \\
\text { groEL5, Putative heat shock protein }\end{array}$ & $\cdots$ & 70 & 3 & 99 & 8 & 24 & $43,022 / 5.81$ & $57,267 / 6.54$ \\
\hline 116 & & groEL & $\ldots$ & 50 & 3 & 165 & 12 & 34 & $56,941 / 5.50$ & $57,847 / 5.23$ \\
\hline 46 & SMc00042 & ilvE2 (2.6.1.42) Aminotransferase & & 201 & 3 & 62 & 8 & 35 & $28,206 / 5.56$ & $34,153 / 5.08$ \\
\hline 4 & SMc00048 & Conserved hypothetical protein & 140 & . & 2 & 46 & 3 & 44 & $13,240 / 5.69$ & $15,199 / 5.32$ \\
\hline 74 & SMc00101 & Oxidoreductase & $\ldots$ & 214 & 3 & 162 & 10 & 60 & $30,022 / 6.81$ & $30,346 / 6.72$ \\
\hline 111 & SMc00154 & gor (EC 1.6.4.2) Glutathione reductase & $\ldots$ & 210 & 3 & 93 & 7 & 27 & $53,926 / 6.42$ & $49,891 / 5.81$ \\
\hline 45 & SMc00265 & Periplasmic binding protein & $\ldots$ & 26 & 3 & 85 & 7 & 25 & $28,899 / 5.50$ & $36,903 / 6.26$ \\
\hline 113 & SMc00335 & rpsA, $30 \mathrm{~S}$ ribosomal protein $\mathrm{S} 1$ & $\ldots$ & 150 & 3 & 218 & 15 & 40 & $60,841 / 5.32$ & $62,602 / 5.12$ \\
\hline \multirow[t]{2}{*}{90} & SMc00347 & rnk, Regulator of nucleoside diphosphate & & & & & & & & \\
\hline & & kinase & $\ldots$ & 39 & 3 & 77 & 5 & 62 & $13,676 / 6.66$ & $14,310 / 6.11$ \\
\hline 10 & SMc00361 & Hypothetical protein & $\ldots$ & 340 & 3 & 87 & 8 & 41 & $34,552 / 5.54$ & $30,529 / 5.26$ \\
\hline 26 & SMc00415 & $\begin{array}{l}\text { dnaN (EC 2.7.7.7) DNA polymerase III, } \\
\text { beta chain }\end{array}$ & $\cdots$ & 40 & 3 & 57 & 5 & 18 & $41,175 / 5.17$ & $40,367 / 5.08$ \\
\hline 103 & SMc00493 & purQ (EC 6.3.5.3) Phosphoribosylformyl & & & & & & & & \\
\hline \multirow[t]{2}{*}{80} & SMc00863 & $\begin{array}{l}\text { glycinamidine synthase } \\
\text { moaB, Molybdenum cofactor biosynthesis }\end{array}$ & $\ldots$ & 150 & 3 & 90 & 6 & 43 & $25,530 / 6.75$ & $23,477 / 6.08$ \\
\hline & & protein B & $\ldots$ & 40 & 1 & 37 & 3 & 27 & $20,828 / 6.35$ & $20,000 / 5.84$ \\
\hline 104 & SMc00912 & groES1, 10-kDa chaperonin A & $\ldots$ & 240 & 3 & 102 & 7 & 52 & $11,632 / 5.68$ & $10,581 / 5.43$ \\
\hline 105 & SMc00913 & groEL1, 60-kDa chaperonin A & $\ldots$ & 240 & 3 & 67 & 6 & 17 & $54,524 / 5.28$ & $57,651 / 5.00$ \\
\hline 115 & SMc00913 & groEL1, 60-kDa chaperonin A & $\ldots$ & 170 & 2 & 41 & 4 & 12 & $55,016 / 5.21$ & $57,651 / 5.00$ \\
\hline 42 & SMc01101 & def1(3.5.1.31) Polypeptide deformylase & $\ldots$ & 274 & 1 & 39 & 4 & 16 & $21,222 / 5.38$ & $19,881 / 4.99$ \\
\hline 29 & SMc01218 & $\begin{array}{l}\text { Transcription elongation factor (transcript } \\
\text { cleavage factor) }\end{array}$ & $\ldots$ & 263 & 3 & 126 & 8 & 59 & $19,546 / 4.98$ & $17,462 / 4.85$ \\
\hline \multirow[t]{2}{*}{44} & SMc01311 & tufA, Elongation factor TU & $\ldots$ & 302 & 3 & 156 & 13 & 48 & $40,881 / 5.54$ & $42,722 / 5.30$ \\
\hline & & & & & & & & & \multicolumn{2}{|c|}{ (continued on next page) } \\
\hline
\end{tabular}

\footnotetext{
${ }^{a}$ Differential accumulation is based on statistical analysis of at least three gels per treatment. Numbers represent average percentage differences in spot volumes between NolR ${ }^{-}$EK698 and NolR ${ }^{+}$AK631, and each value is significant at the $P=0.05$ level; Early $=$ early log phase; Stationary $=$ stationary phase; missing (Miss) and New refer to polypeptides not detectable in the mutant EK698 and wild-type AK631, respectively.

${ }^{\mathrm{b}}$ Peak $=$ Number of peak matched and Seq. $(\%)=$ percent sequence coverage.

${ }^{\mathrm{c}} \mathrm{MW}=$ molecular weight, $\mathrm{pI}=$ isoelectric point, Exp. $=$ experimental, and Theor. $=$ theoretical.

${ }^{\mathrm{d}}$ Genomic accession numbers. Smc, Sma, and Smb refer to products of open reading frames located on the chromosome and symbiotic plasmids A and B, respectively, in S. meliloti 1021 proteomic database. P28267 is a SwissProt accession number.

${ }^{\mathrm{e}}$ Confidence ratings: 3 = all criteria were met and with probability-based Mowse scores greater than 50; $2=$ one criterion was not met with probability-based Mowse scores between 40 and 50; and $1=$ at least one of the criteria met with probability-based Mowse score between 30 and 40.
} 
tween nolR expression and the growing cell number further supports the idea that elevated nolR::lacZ fusion activities are population density dependent. However, this finding was not in line with earlier conclusions made by Cren and associates (1995), who stated that the nolR expression "did not depend on the growth phase of the bacteria, at least in the optical density $\left(\mathrm{OD}_{600}\right)$ range $0.1-1.0$." This may be due to the fact that the nolR expression activity was not measured throughout the complete bacterial growth cycle in Cren's experiments. Actually, there was not much difference in the nolR expression levels if the cultures were tested with $\mathrm{OD}_{600}$ between 0.1 and 1.0 (Fig. 1).

\section{NolR expression and quorum sensing signals.}

In bacteria, the regulation of gene expression in response to fluctuations in cell population density relies on a system of signaling between cells known as quorum sensing. Quorum sensing bacteria produce diffusible signal molecules that increase in concentration as a function of cell density. Populationdensity-dependent regulation of nolR suggests that quorum sensing may control NolR production in S. meliloti AK631.
This was supported by stimulation of nolR by quorum factors in the supernatants of the stationary-phase cultures. The significant stimulation of nolR expression by quorum factors occurred in the early-log-phase cultures but not in the middlelog-phase cultures. Presumably, amounts of quorum sensing signals produced in the middle-log-phase cultures are high enough for induction of nolR. AHLs are the most common quorum sensing signals among gram-negative bacteria. Strain AK631 produced several novel short- and long-chain AHLs in the defined medium (Teplitski et al. 2003). It will be interesting to see whether either of these AHLs is able to induce nolR expression, or if the induction is caused by another quorum sensing active component. Negative regulation of nodulation genes by quorum sensing has been reported in B. japonicum (Loh et al. 2001). A NolR-like repressor protein, NodD2, is required for repressing the nodulation genes (Garcia et al. 1996; Gillette and Elkan 1996). NodD2 is induced by bradyoxetin, a novel quorum sensing signal which is different from common AHLs detected in Rhizobium spp. (Loh et al. 2002), through a quorum sensing cascade system (González and Marketon 2003).

Table 3. (Continued from preceding page)

\begin{tabular}{|c|c|c|c|c|c|c|c|c|c|c|}
\hline \multirow[b]{2}{*}{ Spot no. } & \multirow[b]{2}{*}{ Accession $^{\mathrm{d}}$} & \multirow[b]{2}{*}{ Protein description } & \multicolumn{3}{|c|}{$\begin{array}{l}\text { Protein accumulation } \\
\text { response }(\%)^{\mathrm{a}}\end{array}$} & \multicolumn{3}{|c|}{ Mascort search results $^{b}$} & \multicolumn{2}{|c|}{$\mathbf{M W} / \mathbf{p} I^{\mathbf{c}}$} \\
\hline & & & Early & Stationary & Rating $^{\mathrm{e}}$ & Score & Peak & Seq. $(\%)$ & Exp. & Theor. \\
\hline$\overline{28}$ & SMc01344 & $\begin{array}{l}\text { accB, Biotin carboxyl carrier protein of } \\
\text { acetyl-CoA carboxylase }\end{array}$ & 327 & & 3 & 58 & 4 & 46 & $19,203 / 4.84$ & $16,521 / 4.71$ \\
\hline 117 & SMc01587 & Conserved hypothetical protein & $\ldots$ & 30 & 3 & 57 & 4 & 32 & $23,928 / 4.66$ & $23,231 / 5.24$ \\
\hline 49 & SMc01613 & $\begin{array}{l}\text { rpiB (5.3.1.6) ribose 5-phosphate } \\
\text { isomerase B }\end{array}$ & 203 & $\ldots$ & 3 & 102 & 6 & 67 & $15,680 / 5.60$ & $15,181 / 5.33$ \\
\hline 50 & SMc01613 & $\begin{array}{l}\text { rpiB (5.3.1.6) ribose 5-phosphate } \\
\text { isomerase B }\end{array}$ & 233 & New & 2 & 45 & 3 & 35 & $14,427 / 5.61$ & $15,181 / 5.33$ \\
\hline 31 & SMc01723 & $\begin{array}{l}\text { Transmembrane hypothetical/global } \\
\text { homology }\end{array}$ & 321 & 53 & 3 & 56 & 4 & 32 & $17,355 / 5.12$ & $18,704 / 4.84$ \\
\hline 84 & SMc01757 & Conserved hypothetical protein & $\ldots$ & 170 & 3 & 76 & 5 & 49 & $13,339 / 6.07$ & $13,453 / 5.67$ \\
\hline 25 & SMc01828 & Transmembrane transport protein & $\ldots$ & 57 & 3 & 136 & 9 & 42 & $40,165 / 5.02$ & $41,062 / 4.99$ \\
\hline 118 & SMc01874 & ftsZ1, Cell division protein & 50 & 50 & 3 & 154 & 12 & 28 & $64,716 / 5.34$ & $62,935 / 5.06$ \\
\hline 107 & SMc02100 & tsf, Elongation factor TS & $\ldots$ & 260 & 3 & 189 & 12 & 56 & $33,639 / 5.53$ & $32,082 / 5.07$ \\
\hline 47 & $\mathrm{SMc} 02122$ & $\begin{array}{l}\text { fpr }(1.18 .1 .2) \text { Ferredoxin-NADP } \\
\text { reductase }\end{array}$ & 192 & 361 & 3 & 169 & 10 & 65 & 26,318/5.64 & $30,319 / 5.30$ \\
\hline 5 & SMc02123 & Conserved hypothetical protein & 67 & $\ldots$ & 3 & 65 & 5 & 37 & $18,437 / 5.82$ & $18,124 / 5.39$ \\
\hline 102 & SMc02171 & $\begin{array}{l}\mathrm{ABC} \text { transporter periplasmic binding } \\
\text { protein }\end{array}$ & & 63 & 3 & 134 & 9 & 43 & $37,205 / 4.57$ & $35,239 / 4.62$ \\
\hline 91 & SMc02351 & Conserved hypothetical protein & 550 & 258 & 3 & 74 & 5 & 54 & $14,479 / 6.53$ & $17,115 / 6.08$ \\
\hline 23 & SMc02365 & degP1 (3.4.21.-) Protease precursor & & 222 & 3 & 142 & 10 & 35 & $60,979 / 4.86$ & $53,003 / 4.80$ \\
\hline 58 & SMc02499 & atpA, ATP synthase alpha chain & 241 & $\ldots$ & 3 & 95 & 8 & 27 & $46,137 / 6.69$ & $54,647 / 6.30$ \\
\hline 59 & SMc02499 & atpA, ATP synthase alpha chain & 320 & $\ldots$ & 3 & 80 & 10 & 23 & $52,692 / 6.69$ & $54,647 / 6.30$ \\
\hline 109 & $\mathrm{SMc} 02509$ & $\begin{array}{l}\text { sitA, } \mathrm{ABC} \text { transporter iron-binding } \\
\text { periplasmic protein }\end{array}$ & $\ldots$ & 60 & 3 & 89 & 6 & 37 & $34,032 / 5.06$ & $32,849 / 5.25$ \\
\hline 67 & SMc02562 & $\begin{array}{l}\text { pckA (4.1.1.49) Phosphoenolpyruvate } \\
\text { carboxykinase }\end{array}$ & 215 & 50 & 3 & 153 & 11 & 34 & $52,692 / 5.92$ & $58,083 / 5.56$ \\
\hline 99 & SMc02761 & trxA, Thioredoxin & 184 & 294 & 2 & 41 & 4 & 38 & $10,809 / 5.04$ & $11,383 / 4.88$ \\
\hline 101 & SMc02857 & $\begin{array}{l}\text { dnaK, heat-shock protein } 70 \text { (hsp70) } \\
\text { chaperone }\end{array}$ & $\ldots$ & 191 & 3 & 135 & 10 & 28 & $67,379 / 5.03$ & $68,907 / 4.91$ \\
\hline 100 & SMc02857 & $\begin{array}{l}\text { dnaK, heat-shock protein } 70 \text { (hsp70) } \\
\text { chaperone }\end{array}$ & & 227 & 3 & 147 & 11 & 29 & $67,321 / 4.99$ & $68,907 / 4.91$ \\
\hline 27 & SMc03019 & fliG, flagellar motor switch protein & 224 & 36 & 2 & 44 & 4 & 20 & $36,451 / 5.18$ & $37,717 / 4.83$ \\
\hline 13 & SMc03091 & argI1 (EC 3.5.3.1) Arginase & . & 420 & 2 & 50 & 6 & 35 & $41,508 / 4.39$ & $32,841 / 5.34$ \\
\hline 21 & SMc03131 & $\begin{array}{l}\mathrm{ABC} \text { transporter amino acid-binding } \\
\text { periplasmic protein }\end{array}$ & 265 & $\ldots$ & 3 & 107 & 7 & 44 & $26,046 / 4.79$ & $30,073 / 4.87$ \\
\hline 75 & SMc03135 & $\begin{array}{l}\text { ABC transporter amino-acid transport } \\
\text { ATP-binding protein }\end{array}$ & 261 & $\ldots$ & 3 & 127 & 14 & 56 & $26,046 / 6.26$ & $28,045 / 5.67$ \\
\hline 110 & SMc03152 & Transmembrane hypothetical & $\ldots$ & 60 & 3 & 79 & 7 & 53 & $26,906 / 5.35$ & $23,937 / 5.04$ \\
\hline 41 & SMc03239 & ppa (EC 3.6.1.1) Inorganic & & & & & & & & 0003665 \\
\hline 9 & SMc03786 & $\begin{array}{l}\text { pyrophosphatase } \\
\text { brf, Bacterioferritin (cytochrome b-1, }\end{array}$ & & 385 & 1 & 39 & 3 & 24 & $19,781 / 5.28$ & $20,036 / 5.67$ \\
\hline 89 & SMc04040 & $\begin{array}{l}\text { ibpA, heat-shock protein } \\
\text { ibst) }\end{array}$ & 241 & $\begin{array}{r}35 \\
442\end{array}$ & $\begin{array}{l}3 \\
3\end{array}$ & $\begin{array}{l}83 \\
55\end{array}$ & $\begin{array}{l}5 \\
6\end{array}$ & $\begin{array}{l}56 \\
39\end{array}$ & $\begin{array}{l}18,269 / 4.92 \\
17,093 / 6.54\end{array}$ & $\begin{array}{l}18,337 / 4.75 \\
17,402 / 6.11\end{array}$ \\
\hline 62 & SMc04262 & $\begin{array}{l}\text { gnd (EC 1.1.1.4) 6-phosphogluconate } \\
\text { dehydrogenase }\end{array}$ & & & & & & & & \\
\hline 93 & P28267 & Nodulation protein NolR (S. meliloti) & Miss & Miss & 3 & 84 & 5 & 64 & $12,159 / 6.40$ & $13,341 / 6.06$ \\
\hline
\end{tabular}




\section{NolR as a regulator of cellular functions.}

NolR has been identified as a repressor protein to control the production of the lipochitooligosaccharide Nod factor required for nodule organogenesis in $S$. meliloti AK631 and $R$. leguminosarum bv. viciae TOM (Kiss et al. 1998). Recently, it has been found in $S$. fredii that NolR controls production of three different symbiotic signals: Nod factors, EPS, and SR proteins secreted from the type III secretion system (Vinardell et al. 2004). Moreover, it has been shown that quorum sensing controls EPS production in $S$. meliloti (Marketon et al. 2003) and, recently, it has been reported that quorum sensing signals regulate type III secretion in the marine bacterium Vibrio harveyi (Henke and Bassler 2004). It is possible that production or secretion of symbiotic signals, such as Nod factors, EPS, and SR proteins in S. meliloti, are under the control of quorum sensing systems and NolR plays a coordinator in these quorum sensing cascade systems to control the secretion of symbiotic signals.

\section{Luteolin addition and NolR regulation.}

Luteolin, an inducer of the common nod genes, originally was reported by Cren and associates to have an inhibitory effect on nolR expression (Cren et al. 1995). In the presence of luteolin at the concentration of $5 \mu \mathrm{M}$, the expression of nolR was lower both in $S$. meliloti $\mathrm{NolR}^{+} \mathrm{AK} 631$ and the NolR $^{-}$mutant EK698 grown in the minimal GTS medium. It was suggested that luteolin indirectly controlled nolR regulation via activation of luteolin-inducible genes (Cren et al. 1995). Surprisingly, the inhibitory effect of luteolin on nolR expression could not be observed in the cells grown in rich TA or minimum BIII medium. In fact, the inhibition of nolR expression by luteolin occurred only when luteolin was added to the early-log-phase GTS cultures of strain AK631 carrying a nolR::lacZ fusion. However, luteolin inhibited not only nolR expression, but bacterial growth as well. Because the level of nolR expression is correlated to cell population density, the lower cell density in the luteolin-containing cultures would have a lower level of nolR expression. Therefore, the inhibitory effect of luteolin on nolR expression observed by Cren and associates (Cren et al. 1995) is the result of the reduction of cell population density of $S$. meliloti cultures by luteolin.
NolR and environmental stimuli and cellular growth.

The expression of the nolR gene also is related to nutrient availability and responsive to various environmental stresses, such as $\mathrm{pH}$ shock and low oxygen level. The expression level was higher in rich media than in minimal media and reduced by extremely acidic or alkaline $\mathrm{pH}$ and lack of oxygen. Nutrientdependent gene expression has been reported in S. meliloti, in which the expression of the $p c k A$ gene was dependent on medium carbon sources, such as succinate and arabinose (Osteras et al. 1995). The fact that nolR is responsive to different environmental stimuli by changing its transcription level suggested that expression of the nolR gene is sensitive to environmental challenge and NolR could act as a regulator in some key metabolic steps, as proposed in previous proteomic studies (Chen et al. 2000b). Presumably, the level of NolR in a culture reflects the sensitivity of this function to the cellular environment, growth medium status, and which metabolic pathways are required by the dividing bacterial cells. These factors would influence the level of the global regulatory role of NolR.

Previous proteomic studies (Chen et al 2000b) and the current proteomic studies of NolR-associated proteins in S. meliloti revealed that some of these proteins are heat-shock proteins. Heat-shock proteins are found in all organisms and presumably protect against thermal damage and accelerate recovery (Eriksson and Clarke 1996). Many heat-shock proteins are molecular chaperones or components of various energy-dependent pathways, which can protect cells during thermal stress by stabilizing protein structure and renaturing unfolded polypeptides (Parcell and Lindquist 1993). When S. meliloti was challenged with heat shock, cells with a functional NolR showed higher thermal tolerance. Those results revealed that NolR plays a role in optimal survival under heat shock, probably via heat shock proteins of a repairing system functioning directly or indirectly within the $n o l R^{+}$cells to help maintain the cellular viability under elevated temperature.

The effect of NolR on S. meliloti growth and survival could not be detected when the cells were grown in rich or defined liquid media, even for as long as 3 weeks. However, when $S$. meliloti cells were grown in a defined liquid medium with much reduced carbon and nitrogen sources, the strain with a functional NolR was found to have a half of a logarithm cell number higher than that without a functional NolR

Table 4. Sinorhizobium meliloti proteins respondent to NolR, acyl homoserine lactones (AHLs), and bacteroids

\begin{tabular}{|c|c|c|c|c|c|}
\hline \multirow[b]{3}{*}{ Protein $^{b}$} & \multirow[b]{3}{*}{ Accession $^{\mathbf{b}}$} & \multicolumn{4}{|c|}{ Differential expression in respond to } \\
\hline & & \multicolumn{2}{|c|}{ NolR ${ }^{\mathbf{a}}$} & \multirow[b]{2}{*}{ AHLs } & \multirow[b]{2}{*}{ Bacteroids $^{c}$} \\
\hline & & Early-log phase & Stationary phase & & \\
\hline Putative heat shock protein groEL & SMb21566 & ... & Downregulated & Upregulated $^{\mathrm{d}, \mathrm{e}}$ & $\ldots$ \\
\hline $30 \mathrm{~S}$ ribosomal protein & SMc00335 & $\ldots$ & Downregulated & Upregulated ${ }^{\mathrm{e}}$ & \\
\hline Polypeptide deformylase & SMc01101 & $\ldots$ & Downregulated & Upregulated $^{\mathrm{d}}$ & $\ldots$ \\
\hline Biotin carboxyl carrier protein of acetyl-CoA carboxylase & SMc01344 & Downregulated & $\ldots$ & Downregulated $^{\mathrm{f}}$ & Upregulated \\
\hline Ribose 5-phosphate isomerase B & SMc01613 & Downregulated & Downregulated & Upregulated $^{\mathrm{d}}$ & ... \\
\hline Cell division protein & $\mathrm{SMc} 01874$ & $\ldots$ & Upregulated & $\ldots$ & Downregulated \\
\hline Ferredoxin--NADP reductase & $\mathrm{SMc} 02122$ & Downregulated & Downregulated & Upregulated $^{\mathrm{d}}$ & ... \\
\hline $\mathrm{ABC}$ transporter periplasmic binding protein & $\mathrm{SMc} 02171$ & $\ldots$ & Upregulated & Upregulated $^{\mathrm{d}}$ & $\ldots$ \\
\hline Protease precursor & $\mathrm{SMc} 02365$ & $\ldots$ & Downregulated & Upregulated ${ }^{\mathrm{d}, \mathrm{e}}$ & Upregulated \\
\hline Phosphoenolpyruvate carboxykinase & $\mathrm{SMc} 02562$ & Downregulated & Upregulated & Upregulated $^{\mathrm{d}, \mathrm{e}}$ & Downregulated \\
\hline Heat shock protein $70(\mathrm{hsp} 70)$ chaperone & $\mathrm{SMc} 02857$ & $\ldots$ & Downregulated & Upregulated ${ }^{\mathrm{g}}$ & Upregulated \\
\hline Heat shock protein & $\mathrm{SMc} 04040$ & Downregulated & Downregulated & $\ldots$ & Upregulated \\
\hline \multirow{3}{*}{\multicolumn{6}{|c|}{$\begin{array}{l}\text { a Based on analysis of the proteins differentially accumulated in early log phase and stationary phase cultures of NolR }{ }^{-} \text {Sinorhizobium meliloti EK698. } \\
\text { b Genomic accession number. Smc, Sma, and Smb refer to products of open reading frames located on the chromosome and symbiotic plasmids A and B } \\
\text { respectively, in the } S \text {. meliloti } 1021 \text { genome database. }\end{array}$}} \\
\hline & & & & & \\
\hline & & & & & \\
\hline \multicolumn{6}{|c|}{${ }^{\mathrm{c}}$ Proteins differentially expressed in bacteroids of S. meliloti 1021 (Natera et al. 2000). } \\
\hline \multicolumn{6}{|c|}{ d Protein was upregulated by AHL 3-oxo-C16:1-HL in S. meliloti 1021 (Chen et al. 2003). } \\
\hline \multicolumn{6}{|c|}{ Protein was upregulated by crude AHLs produced by S. meliloti 1021 (Teplitski et al. 2004). } \\
\hline \multicolumn{6}{|c|}{${ }^{\mathrm{f}}$ Protein was downregulated by AHL C14-HL in S. meliloti 1021 (Chen et al. 2003). } \\
\hline g Protein was upreoulated by unidentified AHLs (Chen un & ublished) & & & & \\
\hline
\end{tabular}


after 1 week of entering the stationary phase. This difference in cell viability was sustained for up to 9 days. These results suggest that the functional NolR is able to sense nutrient stress during bacterial growth that leads to the induction of a cellular adaptation mechanism and improves stationaryphase survival of $S$. meliloti. Rhizobia are free-living organisms in the soil when not in symbiotic association with legumes. In the soil, with little available nutrients, the bacteria cease to increase their biomass during stationary phase. In $R$. leguminosarum bv. phaseoli, cells survived under carbon-, nitrogen-, and phosphorus-starved conditions for at least 2 months (Thorne and Williams 1997). The starved cells had a low level of cell division and were cross-protected against some environmental shocks (Thorne and Williams 1999). There also is considerable evidence to suggest that starved cultures are not static populations (Zambrano et al. 1993), and continued protein synthesis was found to be essential for starvation survival in Staphylococcus aureus (Watson et al. 1998). In Escherichia coli, the rpoS gene encoding the sigma $\mathrm{S}$ subunit is required for prolonged survival in the stationary phase in both nutrient-rich and minimal media (Lange and Hengge-Aronis 1991) and nitrogen-starved minimal media (Kabir et al. 2004). Possible explanations of NolR's response to starvation stress resistance include i) NolR might detect the starvation stress signals, activated by the overlapping pathways related to population density (which often is mediated by sigma factors), and therefore is able to protect cell viability by directly or indirectly affecting the levels of some key macromolecular synthesis; and ii) NolR itself is responsive to starvation stress signals, which in turn activates related population density signals (for example, sigma factors), resulting in the regulation of essential genes to maintain viability during stationary-phase starvation and to generate crossresistance to other environmental stresses, such as heat shock.

Further studies of shifting stationary-phase cells from nutrient-limited medium onto plates of rich medium saw the adjustment of NolR to a "step-up" medium. Cells with functional NolR were found to have a higher cell division rate than those without, indicating that these cells can recover much more quickly from starvation once the nutrients are provided. In nature, bacteria often must cope with hostile environmental conditions by developing sophisticated cooperative behavior and intricate communication capabilities, such as direct cell-to-cell physical interactions via extramembrane polymers, collective production of extracellular fluid for movements on hard surfaces, and long-range chemical signaling such as quorum sensing and chemotactic signaling (Ben-Jacob et al. 2000). The growth of a bacterial colony depends on two local conditions: multiplication rate of bacteria in the surface and occupation rates of the sites of the cluster inside a small circle around the potential growth site, representing the nutrient concentration (Li et al. 1995). The elevation of nolR was found to be population density and medium dependent, which means cells with functional NolR have better communication capabilities and can quickly turn on the synthesis of macromolecules; hence, they have a higher rate of cell division and better adaptation to changed environments from liquid medium to agar plates and more nutrients. Actually, a cell-division protein encoded by ftsZ1 gene (SMc01874) was found to be downregulated in the NolR $^{-}$S. meliloti AK698 in the current (Table 3) and previous studies (Chen et al. 2000b). It will be interesting to test whether the expression of ftsZ1 is directly regulated by NolR and involved in colony development of $S$. meliloti AK631 on solid medium.

Interestingly, NolR was found to be involved in conjugative transfer of plasmids. The frequency of plasmid transfer was increased greatly by a recipient that carried a functional NolR.
This recipient-induced plasmid transfer has been reported in Enterococcus faecalis (Dunny et al. 1995) and R. leguminosarum bv. viciae (Danino et al. 2003). In E. faecalis, conjugative transfer of plasmids to a potential recipient is induced by the small peptides released from the recipient. In $R$. leguminosarum bv. viciae, recipient-induced plasmid transfer is dependent on the production of an AHL (3-OH-C $14: 1-\mathrm{HSL})$ by the recipient. In addition to $R$. leguminosarum bv. viciae, the production of 3$\mathrm{OH}-\mathrm{C}_{14: 1}$-HSL has been detected in R. etli (Daniels et al. 2002) but not in the culture supernatants of $S$. meliloti (Marketon et al 2002; Teplitski et al. 2003). It is possible that, as a global regulatory protein, NolR plays a role in the control of recipient cells excreting signal molecules into medium where they can diffuse to a potential donor cell and induce expression of conjugative transfer functions.

\section{Proteomic analysis.}

Proteomic analysis of $S$. meliloti revealed that at least 59 proteins were significantly altered in protein levels in a strain lacking a functional NolR grown at both the early-log and stationary phase. In the early-log-phase cultures, there were 20 proteins regulated by NolR. Among these 20 proteins, 17 proteins were downregulated by NolR and only 3 proteins were upregulated by NolR. In the stationary-phase cultures, there were 48 NolR-regulated proteins. Among these, 23 were upregulated and 25 were downregulated by NolR. These results indicate that NolR acts mainly as a repressor in cells grown at the early-log-phase cultures whereas, in the stationary-phase cultures, NolR acts as both repressor and activator. Using PMF analysis and the $S$. meliloti 1021 proteomic database search, 59 NolR-associated proteins were identified. The identified proteins involve various metabolic pathways and cellular functions, including amino acid metabolism, carbohydrate metabolism, lipid metabolism, nucleotide metabolism, energy metabolism, metabolism of Co-factors, adaptation, and transportation. These results further support the view that NolR is a global regulator (Chen et al. 2000b). In S. meliloti, NodD is a regulatory protein specific for induction of nodulation genes. However, NodD is a low-abundant protein and has not been detected on $2 \mathrm{D}$ gels from $S$. meliloti stains grown in various media supplemented with or without the nodD inducer luteolin (H. Chen, unpublished data). In contrast to NodD, NolR is an abundant protein which appears as a major spot on 2D gels; perhaps this high level is consistent with its global regulatory functions. The NolR protein was found only in the wild type, AK631, but not in its mutant, EK698, confirming that no functional NolR protein is produced in the Tn5-induced nolR mutant EK698.

An earlier proteome study of NolR-associated proteins in $S$. meliloti found that, from silver-stained 2D gels, over 100 protein spots were differentially accumulated in the stationaryphase cells of the NolR ${ }^{-}$strain EK698 (Chen et al. 2000b). It was possible to isolate 52 spots from Coomassie-stained preparative $2 \mathrm{D}$ gels or polyvinylidene difluoride membranes blotted from preparative gels. Among the 52 spots, 38 were identified by $N$-terminal sequencing and PMF. However, only six spots were identified as $S$. meliloti proteins (Chen et al. 2000b). This was due to the unavailability of the $S$. meliloti 1021 genome database at that time. In the present study, PMF and the $S$. meliloti 1021 proteomic database search have been applied to identify NolR-associated $S$. meliloti proteins. This has allowed us to obtain $S$. meliloti protein identification of all 59 detected NolR-associated protein spots. There were 23 NolR-associated protein spots detected in both the previous and present studies. Among the 23 spots, 11 proteins were identified as NolR-associated in stationary phase cultures by $\mathrm{N}$-terminal sequencing in the previous study and by PMF in the present study. These include elongation factor $\mathrm{TS}, \mathrm{ABC}$ transporter iron-binding 
periplasmic protein, inorganic pyrophosphatase, heat shock protein 70 chaperone, $10-\mathrm{kDa}$ chaperonin $\mathrm{A}, 60-\mathrm{kDa}$ chaperonin A (two isoformers), DNA polymerase III $\beta$ chain, transmembrane hypothetical proteins, and two hypothetical proteins. Two proteins, putative heat-shock protein GroEL and a cell-division protein, were identified as NolR-associated in stationary-phase cultures by PMF in the previous and present study. Another 10 spots were detected as NolR-associated in the previous and present study. Through the search against the $S$. meliloti 1021 protein database, however, these 10 spots were identified by PMF in the present study but not identified by $N$-terminal sequences in the previous study (Chen et al. 2000b). Our results are in agreement with the suggestion made by Mathesius and associates that, in bacterial strains, PMF is more reliable for species-specific protein identification than $\mathrm{N}$-terminal sequencing (Mathesius et al. 2002).

Because most of the NolR-associated proteins were differentially regulated during stationary-phase growth, expression of genes encoding these proteins might be population density dependent and mediated by quorum sensing systems. This possibility was supported by the results that the levels of 10 NolRassociated proteins also were found to be altered in $S$. meliloti 1021 by the addition of AHL quorum sensing signals (Chen et al. 2003, Teplitski et al. 2004). Strain AK631 is very similar to strain 1021 with regards to nodulation and nitrogen-fixation specificities on their host medics plants. It is possible that both NolR and AHL quorum sensing signals are involved in $S$. meliloti stationary-phase adaptation. The growth state of bacteroids can be regarded as similar to free-living rhizobia grown at stationary phase. Interestingly, six NolR-associated proteins also were differentially regulated in bacteroids of $S$. meliloti 1021 (Natera et al. 2000). Among these six proteins, four also were regulated in S. meliloti 1021 by the addition of AHLs. These results suggest that there is an overlap among gene networks that are regulated by NolR, quorum sensing, and bacteroids. Bacterial adaptation into stationary phase is a complex process involving global regulation of gene expression (Ishihama 1997). This adaptation process should be regulated by multiple regulators. Because proteomic analysis can provide an overview of the possible functions of an organism at the protein level, it can be applied to uncover networks of coordinately regulated genes that may play cooperative roles in many bacterial physiological situations, such as stationary-phase adaptation.

\section{Conclusion.}

NolR is a global regulator in $S$. meliloti. The functional NolR is not an obligatory regulator protein, but it is important for the optimization of nodulation, bacterial growth on solid medium, survival under stress conditions, and conjugative transfer of plasmids.

\section{MATERIALS AND METHODS}

\section{Bacterial strains, plasmids, and media.}

S. meliloti strains used were AK631 (Rm41 exoB nolR $\left.{ }^{+}\right)$ (Kondorosi et al. 1989b), EK698 (AK631 nolR::Tn5) (Kondorosi et al. 1991), AK631 carrying a nolR::lacZ fusion, and EK698 carrying a nolR-lacZ fusion (Cren et al. 1995). Plasmids used for conjugative transfer were pRT311 (a transcriptional fusion between the $R$. leguminosarum bv. trifolii nodA promoter and the lacZ gene (Innes et al. 1985) and pRK2013, a helper for plasmid transfer (Figurski and Helinski 1979). The following growth media were used: rich TA medium (Orosz et al. 1973), BIII minimal medium (Dazzo 1982), nutrient-limited BIII medium (mannitol at $0.2 \mathrm{~g} \mathrm{liter}^{-1}$ and glutamate at $0.5 \mathrm{~g}$ liter $^{-1}$ as carbon and nitrogen sources), modified
TM minimal medium (Innes et al. 1985), Luria-Bertani medium (Miller 1972), and GTS minimal medium (Kondorosi et al. 1984).

\section{Microbiological techniques.}

S. meliloti strains were grown at $28^{\circ} \mathrm{C}$ and Escherichia coli strains were grown at $37^{\circ} \mathrm{C}$. Bacterial growth was monitored at $600 \mathrm{~nm}$ using an Ultrospee 2000 spectrophotometer (Pharmacia Biotech, Uppsala, Sweden). Units of $\beta$-galactosidase activity were measured using a modified Miller method (Miller 1972). The supernatants of TA cultures of AK631 $\left(\mathrm{OD}_{600}>1.8\right)$ were prepared by centrifugation of the culture at $6,000 \times g$ for 10 min and filter sterilization $(0.2-\mu \mathrm{m}$ filter $)$ of the supernatant. Anaerobic incubation of the bacteria was carried out by flowing nitrogen gas at $10 \mathrm{kPa}$ for $30 \mathrm{~min}$ into overnight TA cultures in flasks, after which the flasks were sealed with rubber stoppers. To resume the oxygen supply, the nitrogen-treated cultures were transferred to sterilized empty flasks. The heatshock treatment was carried out by placing 1.5-ml Eppendorf tubes containing $0.1 \mathrm{ml}$ of the 2-day-old TA culture into a rack in a $46^{\circ} \mathrm{C}$ water bath. After heat-shock treatment of up to $6 \mathrm{~h}$, the surviving cells were detected by viable counts. Plasmid pRT311 was transferred to strains AK631 and EK698 with helper plasmid pRK2013 by a triparental patch-mating technique (Ditta et al. 1980). Bacterial matings were carried out on TA medium at $28^{\circ} \mathrm{C}$. Transconjugants were counterselected on the modified TMR medium containing tetracycline at $5 \mu \mathrm{g} \mathrm{ml}^{-1}$.

\section{Protein extraction, separation, quantification, and identification.}

Proteins were extracted from cells grown in TA to early-log phase (at $\mathrm{OD}_{600}$ of approximately 0.1 to 0.2 ) or to stationary phase (at $\mathrm{OD}_{600}$ of approximately 1.8 to 1.9 ) as described (Chen et al. 2000a) and quantified based on a modified Bradford protein assay (Guerreiro et al. 1999). Protein concentrations were normalized and the samples were subjected to 2D gel separation as described (Chen et al. 2000a). Preparative gels were stained with Coomassie Brilliant Blue in a stepwise colloidal staining procedure (Neuhoff et al. 1988). Digitized images (600 dots per inch) of the stained gels were quantified using MELANIE 4 image analysis software (Bio-Rad, Hercules, CA, U.S.A.). Protein spot locations were compared with 10 landmark proteins and matched against a specialized proteomic database for S. meliloti 1021 (Weiller et al. 2001). OD of each spot over its area (volume) as a percentage of the relative OD of the gel image (percent volume) was used to quantify each spot. Digitized spot images were statistically analyzed using GenStat 4.2 software as described by Mathesius and associates (2003). A polypeptide was deemed differentially accumulated if $\chi^{2}$ was less than 0.05 .

Proteins were identified by tryptic digestion of the polypeptides isolated from the Coomassie-stained gels followed by PMF with MALDITOF mass spectrometry performed on a Micromass TofSpec 2E Time of Flight Mass Spectrometer (Bruker Daltonik GmbH, Leipzig, Germany). Peptide mass fingerprints were identified by comparison with the S. meliloti 1021 proteomic database using Mascot software (Micromass; Waters Corp., Milford, MA, U.S.A.) as described previously (Weiller et al. 2001). Scoring of PMF matches was based on the following criteria: i) a minimum three peptides matched within 100 ppm to the theoretical mass of the polypeptide without any protein modification, ii) good agreement between the actual and predicated molecular mass and $\mathrm{p} I$, and iii) the absence of other polypeptides that match. A confidence rating of 3 was assigned if all criteria were met and if the probability-based Mowse scores were greater than 50; a rating of 2 was assigned if one criterion was not met and if the probability-based 
Mowse scores was between 40 and 50; and a confidence rating of 1 meant that at least one of the criteria was met and the probability-based Mowse score was between 30 and 40 .

\section{ACKNOWLEDGMENTS}

This study was partially supported by the Australian Research Council for a Centre of Excellence funding. We thank D. Bauer for critical reading of the manuscript and the Australian Proteome Analysis Facility (APAF) for doing the peptide mass fingerprints.

\section{LITERATURE CITED}

Ben-Jacob, E., Cohen, I., and Levine, H. 2000. Cooperative self-organization of microorganisms. Adv. Physics 49:395-554.

Brelles-Marino, G., and Bedmar, E. J. 2001. Detection, purification and characterisation of quorum-sensing signal molecules in plant-associated bacteria. J. Biotechnol. 91:191-209.

Chen, H., Higgins, J., Oresnik, I. J., Hynes, M. F., Natera, S., Djordjevic, M. A., Weinman, J. J., and Rolfe, B. G. 2000a. Proteome analysis demonstrates complex replicon and luteolin interactions in pSyma-cured derivatives of Sinorhizobium meliloti strain 2011. Electrophoresis 21:3833-3842.

Chen, H. C., Higgins, J., Kondorosi, A., Kondorosi, E., Djordjevic, M. A. Weinman, J. J., and Rolfe, B. G. 2000b. Identification of nolR-regulated proteins in Sinorhizobium meliloti using proteome analysis. Electrophoresis 21:3823-3832.

Chen, H., Teplitski, M., Robinson, J. B., Rolfe, B. G., and Bauer, W. D. 2003. Proteomic analysis of wild-type Sinorhizobium meliloti responses to $\mathrm{N}$-acyl homoserine lactone quorum-sensing signals and the transition to stationary phase. J Bacteriol. 185:5029-5036.

Cren, M., Kondorosi, E., and Kondorosi, A. 1994. An insertion point inactivates NolR repressor in Rhizobium meliloti 1021. J. Bacteriol. 176:518-519.

Cren, M., Kondorosi, A., and Kondorosi, E. 1995. NolR controls expression of $R$. meliloti nodulations genes involved in the core Nod factor synthesis. Mol. Microbiol. 15:733-747.

Daniels, R., De Vos, D. E., Desair, J., Raedschelders, G., Luyten, E., Rosemeyer, V., Verreth, C., Schoeters, E., Vanderleyden, J., and Michiels, J. 2002. The cin quorum sensing locus of Rhizobium etli CNPAF512 affects growth and symbiotic nitrogen fixation. J. Biol. Chem. 277:462-468.

Danino, V. E., Wilkinson, A., Edwards, A., and Downie, J. A. 2003. Recipient-induced transfer of the symbiotic plasmid pRL1JI in Rhizobium leguminosarum bv. viciae is regulated by a quorum-sensing relay. Mol. Microbiol. 50:511-525.

Dazzo, F. B. 1982. Leguminous root nodules. Pages 431-446 in: Experimental Microbial Ecology. R. G. Burns and J. L. Slater, ed. Blackwell Scientific, Oxford.

Ditta, G., Stanfield, S., Corbin, D., and Helinski, D. R. 1980. Broad host range DNA cloning system for gram-negative bacteria: Construction of a gene bank of Rhizobium meliloti. Proc. Natl. Acad. Sci. U.S.A. 77:7347-7351.

Dunny, G. M., Leonard, B. A., and Hedberg, P. J. 1995. Pheromone-inducible conjugation in Enterococcus faecalis: Interbacterial and host-parasite chemical communication. J. Bacteriol. 177:871-876.

Eriksson, M., and Clarke, A. K. 1996. The heat shock protein ClpB mediates the development of thermotolerance in the Cyanobacterium Synechococcus sp. strain PCC 7942. J. Bacteriol. 178:4839-4846.

Figurski, D. H., and Helinski, D. R. 1979. Replication of an origin-containing derivative of plasmid RK2 dependent on a plasmid function provided in trans. Proc. Natl. Acad. Sci. U.S.A. 76:1648-1652.

Garcia, M., Dunlap, J., Loh, J., and Stacey, G. 1996. Phenotypic characterization and regulation of the nolA gene of Bradyrhizobium japonicum. Mol. Plant-Microbe Interact. 9:625-636.

Gillette, W. K., and Elkan, G. H. 1996. Bradyrhizobium (Arachis) sp. strain NC92 contains two nodD genes involved in the repression of nodA and a nolA gene required for the efficient nodulation of host plants. J. Bacteriol. 178:2757-2766.

González, J. E., and Marketon, M. M. 2003. Quorum sensing in nitrogenfixing rhizobia. Microbiol. Mol. Biol. Rev. 67:574-592.

Guerreiro, N., Djordjevic, M. A., and Rolfe, B. G. 1999. Proteome analysis of the model microsymbiont Sinorhizobium meliloti isolation and characterisation of novel proteins. Electrophoresis 20:818-825.

Henke, J. M., and Bassler, B. L. 2004. Quorum sensing regulates type III secretion in Vibrio harveyi and Vibrio parahaemolyticus. J. Bacteriol. 186:3794-3805.

Hoang, H. H., Becker, A. and Gonzalez, J. E. 2004. The LuxR homolog
ExpR, in combination with the Sin quorum sensing system, plays a central role in Sinorhizobium meliloti gene expression. J. Bacteriol. 186:5460-5472.

Innes, R., Kuempel, P., Plazinski, J., Canter-Cremers, H., Rolfe, B., and Djordjevic, M. 1985. Plant factors induce expression of nodulation and host-range genes in Rhizobium trifolii. Mol. Gen. Genet. 201:426-432.

Ishihama, A. 1997. Adaptation of gene expression in stationary phase bacteria. Curr. Opin. Genet. Dev. 7:582-588.

Kabir, M. S., Sagara, T., Oshima, T., Kawagoe, Y., Mori, H., Tsunedomi, R., and Yamada, M. 2004. Effects of mutations in the rpoS gene on cell viability and global gene expression under nitrogen starvation in Escherichia coli. Microbiol. 150:2543-2553.

Kiss, E., Mergaert, P., Olah, B., Kereszt, A., Staehelin, C., Davies, A. E., and Downie, J. A. 1998. Conservation of nolR in the Sinorhizobium and Rhizobium Genera of the Rhizobiaceae family. Mol. Plant-Microbe Interact. 11:1186-1195.

Kondorosi, E., Banfalvi, Z., and Kondorosi, A. 1984. Physical and genetic analysis of a symbiotic region of $R$. meliloti: Identification of nodulation genes. Mol. Gen. Genet. 193:445-452.

Kondorosi, A., Kondorosi, E., Györgypál, Z., Bánfalvi, Z., Gyuris, J., Putnoky, P., Grosskopf, E., John, M., Schmidt, J., Ha, D. T. C., Lados, M., Horváth, B., Slaska-Kiss, K., and Schell, J. 1989a. Molecular genetic basis of Rhizobium-legume interactions. Genome 31:350-353.

Kondorosi, E., Gyuris, J., Schmidt, J., John, M., Duda, E., Hoffman, B., Schell, J., and Kondorosi, A. 1989b. Positive and negative control of nod gene expression in $R$. meliloti is required for optimal nodulation. EMBO (Eur. Mol. Biol. Organ.) J. 8:1331-1340.

Kondorosi, E., Pierre, M., Cren, M., Haumann, U., Hoffman, B., Schell, J., and Kondorosi, A. 1991. Identification of NolR, a negative transacting factor controlling the nod regulation in Rhizobium meliloti. J. Mol. Biol. 222:885-896

Lange, R., and Hengge-Aronis, R. 1991. Identification of a central regulator of stationary-phase gene expression in Escherichia coli. Mol. Microbiol. 5:49-59.

Li, B., Wang, J., Wang, B., Liu, W., and Wu, Z. 1995. Computer simulation of bacterial-colony formation. Europhysics 30:239-243.

Loh, J. T., Yuen-Tsai, J. P.-Y., Stacey, M. G., Lohar, D., Welborn, A., and Stacey, G. 2001. Population density-dependent regulation of the Bradyrhizobium japonicum nodulation genes. Mol. Microbiol. 42:37-46.

Loh, J., Carlson, R. W., York, W. S., and Stacey, G. 2002. Bradyoxetin, a unique chemical signal involved in symbiotic gene regulation. Proc. Natl. Acad. Sci. U.S.A. 99:14446-14451.

Long, S. 1996. Rhizobium symbiosis: nod factors in perspective. Plant Cell 8:1885-1898.

Marketon, M. M., Gronquist, M. R., Eberhard, A., and González, J. E. 2002. Characterization of the Sinorhizobium meliloti $\operatorname{sinR} / \operatorname{sinI}$ locus and the production of novel $\mathrm{N}$-acyl homoserine lactones. J. Bacteriol. 184:5686-5695.

Marketon, M. M., Glenn, S. A., Eberhard, A. and González, J. E. 2003. Quorum sensing controls exopolysaccharide production in Sinorhizobium meliloti. J. Bacteriol. 185:325-331.

Mathesius, U., Imin, N., Chen, H., Dordjevic, M., Weinman, J., Natera, S., Morris, A., Kerim, T., Paul, S., Menzel, C., Weiller, G., and Rolfe, B. 2002. Evaluation of proteome reference maps for cross-species identification of proteins by peptide mass fingerprinting. Proteomics 2:12881303.

Mathesius, U., Mulders, S., Gao, M., Teplitski, M., Caetano-Anolles, G., Rolfe, B. G., and Bauer, W. D. 2003. Extensive and specific responses of a eukaryote to bacterial quorum-sensing signals. Proc. Natl. Acad. Sci. U.S.A. 100:1444-1449.

Miller, J. H. 1972. Pages 352-355 in: Experiments in Molecular Genetics. Cold Spring Harbor Laboratory Press, Cold Spring Harbor, NY, U.S.A.

Natera, S., Guerreiro, N., and Djordjevic, M. 2000. Proteome analysis of differentially displayed proteins as a tool for the investigation of symbiosis. Mol. Plant-Microbe Interact. 13:995-1009.

Neuhoff, V., Arold, N., Taube, D., and Ehrhardt, W. 1988. Improved staining of proteins in polyacrylamide gels including isoelectric focusing gels with clear background at nanogram sensitivity using Coomassie Brilliant Blue G-250 and R-250. Electrophoresis 9:255-262.

Orosz, L., Svab, Z., Kondorosi, A., and Sik, T. 1973. Genetic studies on rhizobiophage 16-3. I. Genes and functions on the chromosome. Mol. Gen. Genet. 125:341-350.

Osteras, M., Driscoll, B. T., and Finan, T. 1995. Molecular and expression analysis of the Rhizobium meliloti phosphoenolpyruvate carboxykinase (pckA) gene. J. Bacteriol. 177:1452-1460.

Parcell, D. A., and Lindquist, S. 1993. The function of heat-shock proteins in stress tolerance: Degradation and reactivation of damaged proteins. Annu. Rev. Genet. 27:437-496.

Teplitski, M., Eberhard, A., Gronquist, M. R., Gao, M., Robinson, J. B., and Bauer, W. D. 2003. Chemical identification of $\mathrm{N}$-acyl homoserine 
lactone quorum-sensing signals produced by Sinorhizobium meliloti strains in defined medium. Arch. Microbiol. 180:494-497.

Teplitski, M., Chen, H., Rajamani, S., Gao, M., Merighi, M., Sayre, R. T., Robinson, J. B., Rolfe, B. G., and Bauer, W. D. 2004. Chlamydomonas reinhardtii secrets compound that mimic bacterial signals and interfere with quorum sensing regulation in bacteria. Plant Physiol. 134:137-146.

Thorne, S., and Williams, H. 1997. Adaptation to nutrient starvation in Rhizobium leguminosarum bv. phaseoli: Analysis of survival, stress resistance, and changes in macromolecular synthesis during entry to and exit from stationary phase. J. Bacteriol. 179:6894-6901.

Thorne, S., and Williams, H. 1999. Cell-density dependent starvation survival of Rhizobium leguminosarum bv. phaseoli: Identification of the role of an $\mathrm{N}$-acyl homoserine lactone in adaptation to stationary phase survival. J. Bacteriol. 181:981-990.

Vinardell, J. M., Ollero, F. J., Hidalgo, A., López-Baena, F. J., Medina, C.,
Ivanov-Vangelov, K., Parada, M., Madinabeitia, N., Espuny Mdel, R., Bellogín, R. A., Camacho, M., Rodríguez-Navarro, D. N., Soria-Díaz, M. E., Gil-Serrano, A. M., and Ruiz-Sainz, J. E. 2004. NolR regulate diverse symbiotic signals of Sinorhizobium fredii HH103. Mol. PlantMicrobe Interact. 17:676-685.

Watson, S. P., Clements, M. O., and Foster, S. J. 1998. Characterization of the starvation-survival response of Staphylococcus aureus. J. Bacteriol. 180:1750-1758.

Weiller, G. F., Djordjevic, M. J., Caraux, G., Chen, H., and Weinman, J. J. 2001. A specialised proteomic database for comparing matrix-assisted laser desorption/ionization-time of flight mass spectrometry data of tryptic peptides with corresponding sequence database segments. Proteomics 1:1489-1494.

Zambrano, M. M., Siegele, D., Almiron, M., Tormo, A., and Kolter, R. 1993. Microbial competition-Escherichia coli mutants that take over stationary phase cultures. Science 259:1757-1760. 